Dept. of Food Hygiene, Animal Health Research Institute, Ismailia Lab., Egypt.

\title{
PROLONG THE SHELF-LIFE OF CHILLED KOFTA USING EXTRACT OF GREEN TEA LEAVES
}

(With 4 Tables)

By

\section{TAKWA H. ISMAIL}

(Received at 2/5/2011)

إطالة فترة الصلاحية للكفتة المبردة باستخدام مستخلص أوراق الشاي الأخضر

\section{تقوي حسبن إسعاعيل}

تم دراسة تأثثر إضافة تركيزات مختلقة من مستخلص الثناي الأخضر إلي اللحم البقري

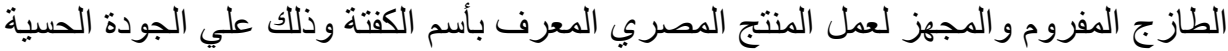

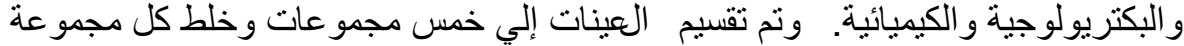

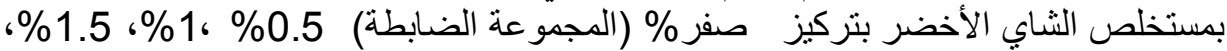

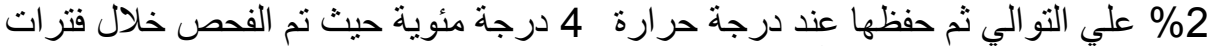

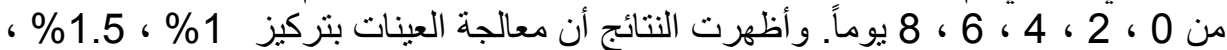

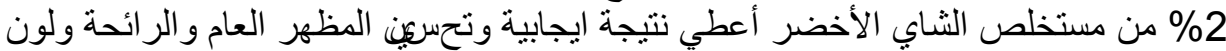

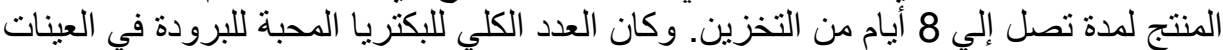

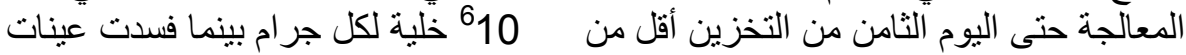

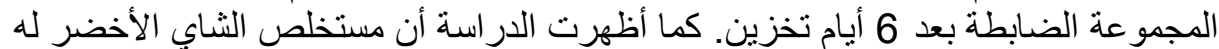

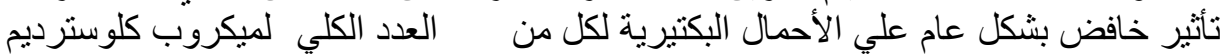

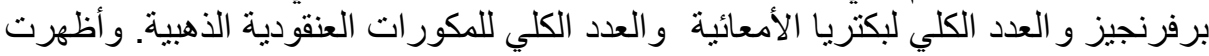

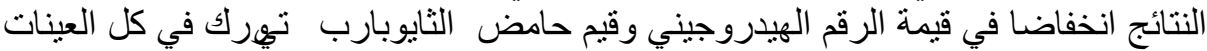

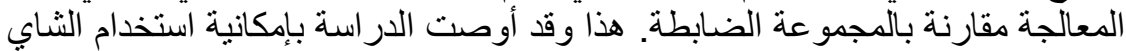

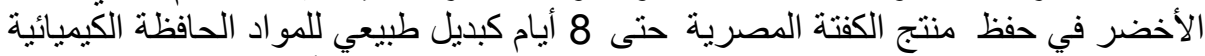
ولتحسين الجودة و إطالة فترة التخزين عند حفظها عند درجة حر ارة أربعة دربية درجات مئوية.

\section{SUMMARY}

The effects of various concentrations of green tea, Camellia sinensis, extract on the sensory, bacteriological and chemical quality of Egyptian traditional Kofta were studied. For this purpose, kofta samples were divided into five groups. First group was kept as a control, others groups were treated with $0.5 \% ; 1.0 \% ; 1.5 \%$ and $2.0 \%$ green tea extract (GTE). All samples were stored at $4{ }^{\circ} \mathrm{C}$ whereas sensory, bacteriological and chemical evaluation of the samples were conducted at $0 ; 2 ; 4 ; 6$ and 8 days post-storage. Flavour and taste were accepted by panelists with 
high score in samples treated with concentrations between 1and 1.5\% GTE. There were marked discoloration changes of kofta samples treated with $2.0 \%$ GTE. Total psychrophiles counts reached the unacceptable count $\left(5 \times 10^{6}\right)$ at $6^{\text {th }}$ day in $0 \%$ control samples while reached $8 \times 10^{5} ; 4 \times$ $10^{5} ; 7 \times 10^{5}$ and $8 \times 10^{4}$ at $8^{\text {th }}$ day in each treated samples with $0.5 \%$; $1.0 \% ; 1.5 \%$ and $2.0 \%$ GTE respectively. Green tea extract showed an inhibitory effect on $C$. perfringens, Enterobacteriaceae and Staphylococcus aureus counts with increased storage time in compared to control samples. Also, beef kofta samples treated with green tea extract showed lower $\mathrm{pH}$ and thiobarbituric acid reactive substance values all over the storage period compared to control. These results suggest that green tea extract treatment could be effectively used to extend the shelf-life of fresh kofta for up to 8 days when stored at $4{ }^{\circ} \mathrm{C}$.

Key words: Green tea leaves, meat products, kofta.

\section{INTRODUCTION}

Egyptian traditional kofta is one of the comminuted meat products and its popularity in all classes of Egyptian society has attracted interest of the meat processors as a business opportunity. The changes in consumer attitudes toward the use of synthetic antimicrobial compounds for prolong their shelf-life and to ensure safety of meat products have been challenge food investigators to seek of naturally compounds those poses antimicrobial properties in foods.

Green tea, Camellia sinensis, extract (GTE) is a highly safe way preserving its value for use in meat, it has antioxidant, deodorant and antimicrobial functions. It is a natural preservative that prolong the shelf-life of foods, enhance quality and provide safer products (Diker et al., 1991; Ji- sun and Yangh, 2007).

Several studies have been revealed to the antimicrobial properties of green tea extract (Ahn et al., 1991; Sakanka et al., 2000; Noriyuki et al., 2001; Kim et al., 2004; Juneja et al., 2007). The extract of green tea leaves has organic compounds including polyphenolic and catchin compounds which has effect against some foodborne pathogens as $E$. coli, Clostridium perfringens, Staph. aureas and Salmonella enteritidis (Kuroda and Hara, 1999; Noriyuki et al., 2001; Friedman, 2007). Catechins can reduce the potential risk of $C l$. perfringens during abusive cooling for beef and chicken. It has more inhibition effect on the extracellular release of verotoxin from enterohemorrhagic Escherichia coli (Sakanaka et al., 2000; Juneja et al., 2007). 
The natural antioxidants as green tea extract decrease malonaldhyde formation which minimize the oxidize ability of fatty acids by chelating iron and copper which cause the disruption of metalcatalyzed free radical formation. It inhibits the formation of lipolytic and proteolytic degradation products and improve the sensorial and physical quality of the treated food (Chander et al., 2005; Hüseyin, 2006; Kumudavally et al., 2008; Dembele et al., 2010). Green tea extract as food additives improved the shelf-life of fresh mutton at ambient storage condition $\left(25 \pm 2{ }^{\circ} \mathrm{C}\right.$ and $\left.85 \pm 5 \% \mathrm{RH}\right)$ and significantly inhibited spoilage microflora, including certain pathogens for up to 4 days, meanwhile control samples showed initial signs of spoilage between 20 and 24 hours (Kumudavally et al., 2008).

Therefore, this study was planned to evaluate the effect of different concentrations of green tea extract as food additives on the sensory, microbial and chemical quality of the traditional Egyptian meat product "Kofta" and their effect on extending the shelf-life of the product under chilling storage.

\section{MATERIALS and METHODS}

Egyptian traditional kofta are produced from a mixture of finely ground meat with cooking salt, onion, and garlic. This mixture is formed into balls ranging in size from a marble to a ping-pong ball and then cooked in griller.

\section{Preparation of Green Tea extract:}

One hundred gram of the grounded leaves was extracted by using technique of James et al. (2010). $500 \mathrm{ml}$ of distilled water were poured in sterile conical flask then covered with aluminum foil and kept at room temperature for 48 hours. After which the extract was obtained by filtering using a filter paper. The extract was concentrated by drying in a water bath maintained at a temperature of $40^{\circ} \mathrm{C}$ until brownish black residues were obtained and these were kept in sealed containers and refrigerated at $3 \pm 1^{\circ} \mathrm{C}$ until required.

\section{Experimental design:}

Fresh beef was purchased from local market at Ismailia city (Egypt) on the day of preparation. Beef was cut and minced with a grinder through a $4 \mathrm{~mm}$ plate diameter. Beef was divided into five groups, each group included 25 samples (each 150g). The five groups were thoroughly mixed in sterile mixer with $0 \%$ (control group), $0.5 \%$, $1 \%, 1.5 \%$ and $2 \%$ green tea extract (GTE) eventually. Each sample was 
made as traditional Egyptian meat product named "Kofta" then wrapped with saran wrap and placed in a chiller at $4^{\circ} \mathrm{C} \pm 1$ for $0,2,4,6$ and 8 day. Five samples were periodically removed for sensory, bacteriological and chemical evaluation as follows:

\section{1- Sensory evaluation:}

The procedure recommended by ASTM (1969) was used for sensory evaluation. Panelists were asked to sign a consent form. Kofta samples were grilled on electric grill for 20 minutes then acceptance testing was used to determine how much each sample was liked based on 5 points according to the guidelines cited below for a set taste, flavour and colour, where $5=$ like excellent and 1 dislike poor.

\begin{tabular}{|c|c|}
\hline Score & Quality Items for Kofta Samples \\
\hline 5 & Natural flavour, color and odour \\
\hline 4 & No sensible change in natural flavor, color, and odour \\
\hline 3 & Sensible discoloration. Slightly sour odour and incipient rancidity in flavour \\
\hline 2 & No natural color, moderately off-odor and off- flavor \\
\hline 1 & Sharply sour and extremely rancid flavour, extremely discolored. \\
\hline
\end{tabular}

Sensory Schema (ASTM, 1969).

\section{2- Bacteriological evaluation:}

The technique recommended by APHA (2001) was used for preparation of Kofta samples. $25 \mathrm{~g}$ of the sample were aseptically removed and homogenized in $225 \mathrm{ml}$ of $1 \%$ sterile buffered peptone water for 2 min using a stomacher 400 lab Blender to provide dilution of $10^{-1}$. From the original homogenate, $1 \mathrm{ml}$ was aseptically transferred to a test tube containing $9 \mathrm{ml}$ sterile buffered peptone water (1\%), from which 10 fold serial dilutions up to $10^{-8}$ were prepared. By using surface plate technique, $0.1 \mathrm{ml}$ from each of the previously prepared dilution was plated as follows: on each duplicate Standard Plate Count Agar for total psychrophiles count (AOAC, 1990), on Lactose Sulphite Broth for C. perfringens (MPN/g) (Beerens et al., 1980), on Violet Red Bile Glucose Agar for total Enterobacteriaceae counts and on Baird Parker Agar with Egg Yolk-Tellurite Emulsion for Staphylococcus aureus count (APHA, 2001).

\section{3- Chemical evaluation:}


a- Determination of $\mathbf{p H}$ : According to the method reported by Benjakul et al. (1997) using pH meter (PH-Meter 761 Calimatic West Germany)

b- Determination of Thiobarbituric Acid Reactive substance (TBARS):

TBARS value was determined by the technique recommended by Vyncke (1970). The absorbance was measured against the blank at $538 \mathrm{~nm}$. TBARS value was expressed as $\mathrm{mg}$ malonaldehyde/kg samples.

\section{RESULTS}

Table 1: Mean values of sensory evaluation of treated beef kofta samples after grilled at the first day.

\begin{tabular}{|c|c|c|}
\hline GTE & Taste & Flavor \\
\hline $0.0 \%$ & 3.8 & 3.9 \\
\hline 0.5 & 4.11 & 4.2 \\
\hline $1 \%$ & 4.60 & 4.2 \\
\hline $1.5 \%$ & 4.3 & 4.1 \\
\hline $2 \%$ & 4.0 & 4.0 \\
\hline
\end{tabular}

Score $=5$ (natural): 1 (no natural)

GTE $=$ Green Tea Extract

Table 2: Mean values of sensory evaluation of treated beef kofta samples during storage at $4 \mathrm{C}^{\mathrm{o}}$

\begin{tabular}{|c|c|c|c|c|c|c|c|c|c|c|c|c|c|c|c|}
\hline $\begin{array}{c}\text { Storage } \\
\text { (day) }\end{array}$ & \multicolumn{3}{|c|}{ Control } & \multicolumn{3}{|c|}{$0.5 \%$ GTE } & \multicolumn{3}{c|}{$1 \%$ GTE } & \multicolumn{3}{c|}{$1.5 \%$ GTE } & \multicolumn{3}{c|}{$2 \%$ GTE } \\
\hline & A & F & C & A & F & C & A & F & C & A & F & C & A & F & C \\
\hline Zero & 5 & 5 & 5 & 5 & 5 & 5 & 5 & 5 & 5 & 5 & 5 & 5 & 5 & 5 & 5 \\
\hline 2 & 3.7 & 3.9 & 3.5 & 4 & 4 & 4 & 4 & 4 & 4.3 & 4.5 & 4.5 & 4.2 & 4.5 & 4.5 & 4 \\
\hline 4 & 3 & 3 & 3 & 3.5 & 3.5 & 3.5 & 4 & 4 & 4 & 4 & 4 & 4 & 4 & 4 & 3.5 \\
\hline 6 & 2 & 2 & 2.5 & 3.5 & 3.2 & 3.5 & 3.8 & 3.9 & 3.7 & 4 & 3.9 & 3.5 & 3.5 & 3.8 & 3.5 \\
\hline 8 & $* \mathrm{~S}$ & $* \mathrm{~S}$ & $* \mathrm{~S}$ & 2.8 & 2.7 & 2.5 & 3.5 & 3.5 & 3.5 & 3.7 & 3.8 & 3 & 3.5 & 3.5 & 3 \\
\hline
\end{tabular}

$\mathrm{A}=$ General appearance $\mathrm{F}=$ flavour

Score: 5 (natural)

$\mathrm{C}=$ colour

GTE $=$ Green tea Extract

1 (no natural)

$* \mathrm{~S}=$ Spoiled 
Table 3: Effect of different concentrations of green tea extract on bacterial quality of beef kofta stored at $4 \mathrm{C}^{\mathrm{o}}(\mathrm{CFU} / \mathrm{g})$.

\begin{tabular}{|c|c|c|c|c|c|c|c|c|c|}
\hline \multicolumn{2}{|c|}{ Time /Day } & \multicolumn{2}{|c|}{ T. Ps.C } & \multicolumn{2}{|c|}{$\begin{array}{c}\text { C. perferingens } \\
\text { MPN/g }\end{array}$} & \multicolumn{2}{|c|}{ Enterobacteriaceae } & \multicolumn{2}{|c|}{ Staph. aureus } \\
\hline & & Mean & S.E. \pm & Mean & S.E. \pm & Mean & S.E. \pm & Mean & S.E. \pm \\
\hline \multirow[t]{5}{*}{ Control } & 0 & $9 \times 10^{3}$ & $3 \times 10^{2}$ & 4 & 1.3 & $3 \times 10^{3}$ & $3 \times 10^{2}$ & $6 \times 10^{3}$ & $2 \times 10^{2}$ \\
\hline & 2 & $3 \times 10^{4}$ & $2 \times 10^{3}$ & 7 & 2.3 & $8 \times 10^{3}$ & $5 \times 10^{2}$ & $9 \times 10^{3}$ & $10^{3}$ \\
\hline & 4 & $8 \times 10^{5}$ & $6 \times 10^{2}$ & ND & - & $6 \times 10^{4}$ & $3 \times 10^{3}$ & $2 \times 10^{4}$ & $6 \times 10^{3}$ \\
\hline & 6 & $5 \times 10^{6}$ & $4 \times 10^{4}$ & ND & - & $8 \times 10^{4}$ & $2 \times 10^{4}$ & $1 \times 10^{5}$ & $2 \times 10^{4}$ \\
\hline & 8 & ${ }^{*} \mathrm{~S}$ & & *S & & *S & & *S & \\
\hline \multirow[t]{5}{*}{$0.5 \%$} & 0 & $6 \times 10^{3}$ & $3 \times 10^{3}$ & 4 & 1.4 & $1 \times 10^{3}$ & $10^{2}$ & $9 \times 10^{2}$ & $10^{2}$ \\
\hline & 2 & $3 \times 10^{4}$ & $2 \times 10^{2}$ & 7 & 2.3 & $4 \times 10^{3}$ & $2 \times 10^{2}$ & $3 \times 10^{3}$ & $8 \times 10^{2}$ \\
\hline & 4 & $5 \times 10^{4}$ & $6 \times 10^{3}$ & ND & - & $1 \times 10^{4}$ & $3 \times 10^{2}$ & $1 \times 10^{4}$ & $7 \times 10^{3}$ \\
\hline & 6 & $3 \times 10^{5}$ & $10^{4}$ & ND & - & $6 \times 10^{4}$ & $4 \times 10^{3}$ & $7 \times 10^{3}$ & $2 \times 10^{2}$ \\
\hline & 8 & $8 \times 10^{5}$ & $6 \times 10^{4}$ & ND & - & $8 \times 10^{4}$ & $2 \times 10^{3}$ & $8 \times 10^{3}$ & $2 \times 10^{2}$ \\
\hline \multirow[t]{5}{*}{$1.0 \%$} & 0 & $3 \times 10^{3}$ & $2 \times 10^{2}$ & 4 & 1.3 & $4 \times 10^{2}$ & $10^{2}$ & $4 \times 10^{2}$ & $2 \times 10^{2}$ \\
\hline & 2 & $6 \times 10^{3}$ & $3 \times 10^{2}$ & ND & - & $4 \times 10^{3}$ & $2 \times 10^{2}$ & $3 \times 10^{3}$ & $10^{3}$ \\
\hline & 4 & $9 \times 10^{3}$ & $10^{2}$ & ND & - & $1 \times 10^{4}$ & $3 \times 10^{2}$ & $3 \times 10^{3}$ & $2 \times 10^{2}$ \\
\hline & 6 & $5 \times 10^{4}$ & $1 \times 10^{3}$ & ND & - & $9 \times 10^{3}$ & $6 \times 10^{2}$ & $6 \times 10^{3}$ & $4 \times 10^{2}$ \\
\hline & 8 & $4 \times 10^{5}$ & $10^{4}$ & ND & - & $3 \times 10^{4}$ & $1 \times 10^{3}$ & $8 \times 10^{3}$ & $3 \times 10^{2}$ \\
\hline \multirow[t]{5}{*}{$1.5 \%$} & 0 & $2 \times 10^{3}$ & $4 \times 10^{2}$ & 3 & - & $2 \times 10^{2}$ & $10^{2}$ & $5 \times 10^{2}$ & $3 \times 10^{2}$ \\
\hline & 2 & $4 \times 10^{3}$ & $10^{3}$ & ND & - & $8 \times 10^{2}$ & $2 \times 10^{2}$ & $4 \times 10^{3}$ & $2 \times 10^{2}$ \\
\hline & 4 & $6 \times 10^{3}$ & $2 \times 10^{3}$ & ND & - & $4 \times 10^{3}$ & $2 \times 10^{2}$ & $3 \times 10^{3}$ & $10^{3}$ \\
\hline & 6 & $5 \times 10^{4}$ & $4 \times 10^{3}$ & ND & - & $8 \times 10^{3}$ & $10^{3}$ & $5 \times 10^{3}$ & $3 \times 10^{2}$ \\
\hline & 8 & $7 \times 10^{5}$ & $3 \times 10^{4}$ & ND & - & $3 \times 10^{4}$ & $6 \times 10^{2}$ & $7 \times 10^{3}$ & $10^{3}$ \\
\hline \multirow[t]{5}{*}{$2.0 \%$} & 0 & $5 \times 10^{3}$ & $2 \times 10^{2}$ & ND & - & $3 \times 10^{2}$ & $10^{2}$ & $5 \times 10^{2}$ & $10^{2}$ \\
\hline & 2 & $3 \times 10^{3}$ & $10^{2}$ & ND & - & $4 \times 10^{3}$ & $6 \times 10^{2}$ & $3 \times 10^{3}$ & $10^{3}$ \\
\hline & 4 & $4 \times 10^{3}$ & $3 \times 10^{2}$ & ND & - & $2 \times 10^{3}$ & $2 \times 10^{2}$ & $3 \times 10^{3}$ & $2 \times 10^{2}$ \\
\hline & 6 & $2 \times 10^{4}$ & $4 \times 10^{3}$ & ND & - & $7 \times 10^{3}$ & $10^{3}$ & $8 \times 10^{3}$ & $4 \times 10^{2}$ \\
\hline & 8 & $8 \times 10^{4}$ & $6 \times 10^{3}$ & ND & - & $2 \times 10^{4}$ & $3 \times 10^{3}$ & $3 \times 10^{3}$ & $10^{3}$ \\
\hline
\end{tabular}

T.PS.C $=$ Total psychrophilic count

${ }^{*} \mathrm{~S}=$ spoiled

$\mathrm{ND}=$ not detected. 
Table 4: Chemical values of treated beef kofta samples stored at $4 \mathrm{C}^{\circ}$

\begin{tabular}{|c|c|c|c|c|c|c|c|c|c|c|}
\hline \multirow{2}{*}{$\begin{array}{c}\text { Time/ } \\
\text { day }\end{array}$} & \multicolumn{9}{|c|}{$\mathrm{pH}$} & \multicolumn{5}{c|}{ TBARS (mg MD/ Kg) } \\
\cline { 2 - 10 } & $0 \%$ & $0.5 \%$ & $1 \%$ & $1.5 \%$ & $2 \%$ & $0 \%$ & $0.5 \%$ & $1 \%$ & $1.5 \%$ & $2 \%$ \\
\hline 0 & $\begin{array}{c}6.08 \\
\pm 0.02\end{array}$ & $\begin{array}{c}5.59 \\
\pm 0.01\end{array}$ & $\begin{array}{c}5.46 \\
\pm 0.032\end{array}$ & $\begin{array}{c}5.52 \\
\pm 0.041\end{array}$ & $\begin{array}{c}5.43 \\
\pm 0.032\end{array}$ & $\begin{array}{c}2.056 \\
\pm 0.39\end{array}$ & $\begin{array}{c}1.168 \\
\pm 0.22\end{array}$ & $\begin{array}{c}1.113 \\
\pm 0.12\end{array}$ & $\begin{array}{c}0.690 \\
\pm 0.09\end{array}$ & $\begin{array}{c}0.558 \\
\pm 0.21\end{array}$ \\
\hline 2 & $\begin{array}{c}6.06 \\
\pm 0.08\end{array}$ & $\begin{array}{c}5.64 \\
\pm 0.04\end{array}$ & $\begin{array}{c}5.60 \\
\pm 0.042\end{array}$ & $\begin{array}{c}5.58 \\
\pm 0.06\end{array}$ & $\begin{array}{c}5.83 \\
\pm 0.09\end{array}$ & $\begin{array}{c}2.032 \\
\pm 0.43\end{array}$ & $\begin{array}{c}1.618 \\
\pm 0.33\end{array}$ & $\begin{array}{c}1.408 \\
\pm 0.22\end{array}$ & $\begin{array}{c}0.992 \\
\pm 0.07\end{array}$ & $\begin{array}{c}0.777 \\
\pm 0.25\end{array}$ \\
\hline 4 & $\begin{array}{c}5.94 \\
\pm 0.092\end{array}$ & $\begin{array}{c}5.68 \\
\pm 0.03\end{array}$ & $\begin{array}{c}5.39 \\
\pm 0.063\end{array}$ & $\begin{array}{c}5.33 \\
\pm 0.034\end{array}$ & $\begin{array}{c}5.15 \\
\pm 0.052\end{array}$ & $\begin{array}{c}1.693 \\
\pm 0.09\end{array}$ & $\begin{array}{c}1.397 \\
\pm 0.43\end{array}$ & $\begin{array}{c}1.317 \\
\pm 0.22\end{array}$ & $\begin{array}{c}1.288 \\
\pm 17\end{array}$ & $\begin{array}{c}1.035 \\
\pm 0.13\end{array}$ \\
\hline 6 & $\begin{array}{c}6.23 \\
\pm 0.06\end{array}$ & $\begin{array}{c}5.82 \\
\pm .062\end{array}$ & $\begin{array}{c}5.72 \\
\pm 0.065\end{array}$ & $\begin{array}{c}5.70 \\
\pm 0.030\end{array}$ & $\begin{array}{c}5.93 \\
\pm 0.042\end{array}$ & $\begin{array}{c}2.169 \\
\pm 0.27\end{array}$ & $\begin{array}{c}1.432 \\
\pm 0.11\end{array}$ & $\begin{array}{c}1.400 \\
\pm 0.32\end{array}$ & $\begin{array}{c}1.311 \\
\pm 0.27\end{array}$ & $\begin{array}{c}1.274 \\
\pm 0.26\end{array}$ \\
\hline 8 & $\begin{array}{c}\mathrm{S} S \\
6.01\end{array}$ & $\begin{array}{c}5.98 \\
\pm 0.031\end{array}$ & $\begin{array}{c}5.90 \\
\pm 0.032\end{array}$ & $\begin{array}{c}5.88 \\
\pm 0.02\end{array}$ & $\begin{array}{c}* \\
\mathrm{~S}\end{array}$ & $\begin{array}{c}1.633 \\
1.580\end{array}$ & $\begin{array}{c}1.423 \\
\pm 0.26\end{array}$ & $\begin{array}{c}1.412 \\
\pm 0.34\end{array}$ & \pm 0.11 & \pm 0.32 \\
\hline
\end{tabular}

$* \mathrm{~S}=$ spoiled

TBARS $=$ Thiobarbituric Acid Reactive Substanc

\section{DISCUSSION}

\section{Sensory Quality}

The results obtained in Table 1 show the sensory scores of grilled kofta after one day of shelf-life. Flavour and taste of control samples were unfavorable and might not be appealing to panelists than other treated samples. Flavour and taste were accepted by panelists with high score in samples treated with concentrations between 1 and 1.5\% GTE. These results agree with those showed by Nirmal and Benjokul (2010). Green tea had not deteriorative changes in the sensory quality of beef steaks when marinated in their extract for six hours at $5^{\circ} \mathrm{C}$ (Qualhas et al., 2010)

The changes in sensory characteristics during 8 days storage at $4^{\circ} \mathrm{C}$ recorded in Table 2 revealed that with extending the shelf-life of the samples, off-flavor was developed in all samples by various scores from low to high score parallel to concentrations of GTE from low to high concentrations. The early signs of off-flavor appeared in control and $0.5 \%$ groups at 6 day storage, and such off-flavour was developed in other treated groups after 6 days of storage. A marked discoloration changes of kofta samples treated 2.0\% GTE was observed, this might be implicated to the possibly penetration of chlorophyll pigments and their subsequent interference with other biochemicaly active compounds in 
beef samples, which caused an undesirable change in meat colour (Sarah et al., 2010). These results agree with those showed by Kumudavally et al. (2008); Jin-ling et al. (2009); Nirmal and Benjakul (2010).

\section{Bacteriological quality:}

From the results given in Table 3 , it is noticed that total psychrophilic count reached the unacceptable limit $\left(10^{6} \mathrm{cfu} / \mathrm{g}\right)$ at $6^{\text {th }}$ day in control group according to Egyptian Organization for Standardization and Quality Control (EOS, 2005). Total psychrophilic counts reached $8 \times 10^{5} ; 4 \times 10^{5} ; 7 \times 10^{5}$ and $8 \times 10^{4} \mathrm{cfu} / \mathrm{g}$ at $8^{\text {th }}$ day in treated samples with $0.5 \% ; 1.0 \% ; 1.5 \%$ and $2.00 \%$ GTE respectively. The antimicrobial effects of green tea extract in meat is well confirmed by Maolinchun (2006); Kang et al. (2007) and Nirmal and Benjakul (2010). The polyphenols of green tea extract had strong effect on the growth of total viable bacteria and total psychrophilic counts at $5^{\text {th }}$ and $10^{\text {th }}$ day during ice storage of fish (Noriyuki et al., 2001).

The acceptable limit for anaerobic spore forming bacteria in meat products do not exceed $10^{2} \mathrm{cfu} / \mathrm{g}$ according to EOS (2005). Clostridium perfringens could be detected in little number of control samples during 0 and 2 day only with a mean value of 4 and 7 respectively. but the pathogen did not recovered from other treated groups. The concentration of 2.0\% GTE samples showed more antimicrobial effect on C. perfringens. Juneja et al. (2007) confirmed that green tea extract has higher catechin content which is effective in controlling $C$. perfringens population densities during cooling of ground beef.

Also Sakanaka et al. (2000) found that the heat resistance Bacillus stearothermmophilus and C. thermoaceticum spores were more rapidly decreased by the addition of green tea polyphenols at high temperature. The differences in the obtained results may be attributed to the findings of Traci and Dunca (1974) who mentioned that a loss in the viability of $C$. perfringens cells may occur if foods were frozen or held under prolonged refrigeration. The inhibitory effects of GTE against C. perfringens were reported by Ahn et al. (1991); Juneja et al. (2006).

Most members of Enterobacteriaceae family are mainly mesophilic while some strains can grow at $0^{\circ} \mathrm{C}$ (Downes and Ito, 2001). The results in Table 3 confirmed the inhibitory effect of different concentrations of GTE compared to control sample. $1.0 \%, 1.5 \%$ and 2.0\% GTE were more effective in lowering the Enterobacteriaceae counts compared to control and 0.5\% GTE groups. These results agree with Byrne (2009) who showed that the population of the pathogenic bacteria in pork loins meat packed with green tea extract film (GTE) 
$2.8 \%$ were significantly reduced during storage at $4 \mathrm{C}^{\circ}$ from $5.47 \mathrm{log}$ cfu/g to 4.47/log cfu/g after 10 days.

The inhibitory effect of green tea extract 2\%, $4 \%$ and $6 \%$ against E. coli, Pseudomonas aeruginosa; Serratia spp.; Bacillus subtilis; Enteobacteriaceae; coliform counts and Listeria monocytogenes were reported by Jin-ling et al.(2009) and Nirmal and Benjakul, (2010).

The results showed that Staph. aureus counts of untreated samples (control) were higher than those of treated samples with GTE where the mean values of Staph. aureus of each treated samples $(0.5 \%$; $1.0 \% ; 1.5 \%$ and $2.0 \%$ ) were $8 \times 10^{3} ; 8 \times 10^{3} ; 7 \times 10^{3}$; and $3 \times 10^{3} \mathrm{cfu} / \mathrm{g}$ respectively at 8 days while the control samples reached $1 \times 10^{5} \mathrm{cfu} / \mathrm{g}$ at 6 day during chilling storage. The antibacterial activities of green tea extract (GTE) against Staphylococcus aureus were reported by Kim et al. (2004); Vasudeo and Sonika (2009) and Javier et al. (2010).

The Egyptian Standardization (EOS, 2005) of frozen ball listed that the permissible limits for Staph. aureus must be not exceed than $10^{2}$ $\mathrm{cfu} / \mathrm{g}$. The inhibitory action of green tea polyphenols and catechin is probably due to their ability to complex with extracellular and soluble proteins and to complex with bacterial cell walls (Sakanaka et al., 1996).

\section{Chemical quality}

The $\mathrm{pH}$ value assessed as a crucial factor for determination of meat quality (Nam et al., 2001), might interfere with solubility activities of antioxidants by changing in their electrical charges (Decker et al., 2005). Changes in $\mathrm{pH}$ value of treated beef kofta samples and control are shown during 8 days storage in Table 4. A gradual increase in the $\mathrm{pH}$ value was detected until day 4 while the $\mathrm{pH}$ values of treated samples showed a degree of stability by an increase in the amount of green tea extract added. The increase in meat $\mathrm{pH}$ value at storage period may be due to an increase in valotile bases compounds produced by either endogenous or microbial enzymes, and decomposition of nitrogenous components and increase of ammonia and free amine group produced in meat (Cann et al., 1983; Sikorski et al., 1990; Benjakul et al. 2002).

$\mathrm{pH}$ values of vacuum infused fresh chicken breast meats with green tea extracts stored at $5^{\circ} \mathrm{C}$ ranged from 5.98 to 6.16 (Rababah et al., 2006-a). There was gradual changes in $\mathrm{pH}$ values of treated fish fillets samples with $1 \%$; and $2.5 \%$ GTE from 6.51 to 6.81 during storage period at $4^{\circ} \mathrm{C}$ (Sarah et al., 2010). Meanwhile, Maolinchun (2006) confirmed that $0.1 \%$ of tea polyphenols had no significant effects on $\mathrm{pH}$ values by dipping of fish in (GTE) for one hour at $3{ }^{\circ} \mathrm{C}$. 
The results obtained in Table 4 revealed that the mean value of TBARS reached $2.161 \mathrm{mg} / \mathrm{kg}$ in the control samples at $6^{\text {th }}$ day, while it reached $1.633 ; 1.580 ; 1.423$ and $1.412 \mathrm{mg} / \mathrm{kg}$ in $0.5 \% ; 1.0 \% ; 1.5 \%$ and $2.0 \%$ (GTE) treated samples at $8^{\text {th }}$ day respectively. The acceptable limit for TBA in meat do not exceed $0.9 \mathrm{mg} / \mathrm{kg}$ according to EOS (2005). It is evident that TBARS increased gradually with the time of meat storage due to formation of maloneldehyde (Gray and Crakal, 1992). Malonaldhyde production in food may be affected by temperature, fat amount in the product, the degree of unsaturation of fatty acids (Devore, 1988). These findings agree with Hüseyin, (2006); Maolinchun, (2006); Ko and Yang, (2008); Jin-ling et al. (2009); Dembele et al. (2010); Nirmal and Benjakul (2010) which confirmed the positive correlation between higher concentrations of green tea extract $(2 \%, 4 \% \& 6 \%)$ (Phenolic and catechins content) and antioxidant properties of these compounds to retard the formation of malonaldehydes and TBARS values, control of lipid oxidation and preventing undesirable change in chemical properties in meat samples.

Furthermore Rababah et al. (2006-a) Found that TBARS values of uncooked (raw) chicken breast meats treated with green tea extract for 0 to 12 day of storage at $5 \mathrm{C}^{\circ}$ ranged from 1.12 to $3.5 \mathrm{mg}$ of malonaldehyde/ $100 \mathrm{~g}$ while (TBARS) ranged from 2.50 to $7.80 \mathrm{mg} / 100 \mathrm{~g}$ and from 2.4 to $7.35 \mathrm{mg} / 100 \mathrm{~g}$ of chicken breast meat cooked by microwave and conventional electric oven, respectively. On the other wise Sarah et al. (2010) found much more reduction of TBARS values in $2.5 \%$ and $5 \%$ GTE treated fish fillets stored up to 8 days at $4 \mathrm{C}^{\circ}$, relative to other samples where (TBARS) valued from 0 to 8 days $(0.13 \pm$ 0.01 to $0.97 \pm 0.09)$ and $(0.11 \pm 0.02$ to $0.80 \pm 0.25)$ for $2.5 \%$ and $5 \%$ GTE respectively, while $1 \%$ GTE were $(0.14 \pm 0.01$ to1.84 \pm 0.09$)$. Rababah et al. (2006-b) also found that TBARS values from 0 to 12 days ranged from (16.1-38.0 mg/kg) and (16.4- $67.8 \mathrm{mg} / \mathrm{kg}$ ) for non irradiated raw chicken breast meat infused with green tea extract (3.000 ppm) and control samples respectively during storage at $5 \mathrm{C}^{\circ}$. Meanwhile Sarker et al. (2010) found that the mean TABA values in fresh broiler meat for control, $0.5 \%$ and $1.0 \%$ green tea samples were $2.31 \pm 0.09 ; 1.69 \pm 0.13$ and $2.22 \pm 0.19 \mathrm{umol} / 100 \mathrm{~g}$, respectively.

In conclusion the addition of 1.0 to $1.5 \%$ green tea extract to traditional Egyptian kofta resulted in the best kofta quality with extending their shelf-life up to 8 day under chilling storage. Panelists accepted the flavour and taste of treated products with concentration up to $1.5 \%$. At this concentration, green tea extract can minimize the 
undesirable changes in microbiological and chemical properties which may be developed during storage.

\section{REFERENCES}

Ahn, Y.J.; Kawamura, Г.; Kim, M.; Yamamoto, $Г$. and Mitsuoka, $Г$. (1991): Tea polyphenols: selective growth inhibitors of Clostridium spp. Agric. Biol. Chem. 55: 1425-1426.

APHA "American Public Health Association" (2001): Compendium of Methods for Microbiological Examination of Food, $4^{\text {th }}$ ed.,Downer, F.P.and Ito, K. (eds) American Public Health Association, Washington, DC., USA.

AOAC (1990): Association of Official Analytic Chemists Official Methods of Analysis, $15^{\text {th }}$ ed, Washington, DC.,USA.

ASTM (1969): Manual on Sensory Testing Methods, American Society for Testing and Materials 1916 Race streed, Pa. 19103, pp: 33-42. Philadelphia.

Beerens, H.; Remond, C.H.; Le page, C. and Criquelion, J. (1980): A direct methods for the enumeration of $\mathrm{Cl}$. perfringens in foods and feaces World Congeress of food- borne Infection and Intoxication. Berlin (West).

Benjakul, S.; Seymour, T. and Morrissey, M. (1997): Physiochemical changes in pacific whiting muscle protein during ice storage.J. Food Sci., 62: 729-733.

Benjakul, S.; Vissanguan, W.; Riébroy, S.; I Shizaki, S. and Tanaka, M. (2002): Gel forming properties of surimi produced from big eye snapper, priacanthustayenus and P.macranthus, stored ice. J. Food Sci ., and Agri., 82: 1442-1451.

Byrne, B.J. (2009): Packaging using natural antimicrobical may protect pork. J. Food Sci., 74, 1.

Cann, D.L.; Smith, G.L. and Houston, N.G. (1983): Futher studies on marine fish stored under modified atomsphere packaging. Aberdeen: Ministry of Agriculture Fisheries and Food, Гorry Research Station. Scotland, pp: 322.

Chander, R.; Khanna, A.K.; Kanwal, R. and Rastogi, A.K. (2005): Antioxidant and lipid lowering activities of Indian black tea. Indian J. Clinical Biochemistry 20: 153-159.

Decker, E.A.; Warner, K.; Richards, M.P. and Shahidi, F. (2005): Measuring antioxidant effectiveness in food. J. Agri. and Food Chemistry, 53: 4303-4310. 
Dembele, S.; Wang, D.F; Yn, L.N.; Sun, J.P. and Dong, S.Y. (2010): Effects of added crude green tea polyphenol on the lipid oxidation of common carp (Cyprinus carpiol) and catfish (Clarias GariepinusBurchell) during refrigerated storage J. of Muscle Foods. 21, 4: 738-756.

Devore, V.R. (1988): TBA values and 7- keto cholesterol in refrigerated raw and ground beef. J. Food Sci., 53(4) I 1058-1061.

Diker, K.S.; Akan, M.; Hascelik, G. and Yurdakok, M. (1991): The bactericidal of tea against Campylobacter jejuni and Campylobacter coli.Lett Appl. Microbil, 12: 34-35.

Downes, F.P. and Ito, K. (2001): Compendium of Methods for the Microbiological Examination of foods. $4^{\text {th }}$ ed. American Public Health Association Press. Washington DC,USA.

EOS (2005): Egyptian Standards, frozen balls. E. S:1973-2005, ICS: 67.120 .10

Friedman, M. (2007): Over view of antibacterial, antitoxin, antiviral and anti-fungal activities of tea compounds. Mol. Nutr. Food Res., 51: 116-134.

Gray, J.I. and Crakal, E.L. (1992): Oxidative flavor changes in meat: their origin and prevention in the chemistry of muscle-based food (ed s.D.E. Johnston, k.knight and D.A.Led ward. Royal society of chemistry, London, pp, 145.

Hüseyin Bozkurt (2006): Utilization of natural antioxidants:Green tea extract and Thymbra spicata oil in Turkish dry fermented sausage. Meat Science, 73, 3: 442-450.

James, D.B.; Owolabi, O.A; Bisalla, M. and Jassium, H. (2010): Effects of aqueous extracts (Leaves and stem) of vitexdoniana on carbon. Tetrachloride induced liver injury in rats. British J. of Pharmacology and Toxicology 1(1):1-5

Javier Rúa; Laura, F.A.; Marta, G.L.; Pilar, D.V.; Dolores, D.A. and Maria, R.G.A. (2010): Screening of phenolic antioxidants for their inhibitory activity against foodborne Staphylococcus aures strains. J. Foodborne Pathgens and Disease, 7, 6: 695-705.

Jin-ling, Qiao; Yong-jin, Hu; Zhen-hui, CAO and Chang-rong, GE. (2009): Effects of green tea extraction preservation of chilled Mutton. Food Sci., 12, 4:42.

Ji-sun Kim and yangha Kim, (2007): The inhibitory effect of natural bioactives on the growth of pathpgeinc bacteria.Nutrition Research and Practice, 1(4): 273-278 
Juneja, V.K; Thippareddi, H. and Friedman, M. (2006): Control of Cl. perfingens in cooked ground beef by carvacrol, cinnamaldehyde, thymol or oregano oil during chilling. J. Food Prot.69: 15 46-1551.

Juneja, V.K; Bari, M.L.; Inatsu, Y.; Kawmoto, S. and Friedman, M. (2007): Control of Clostridium perfringens spores by green tea leaf extracts during cooling of cooked ground beef, chicken and pork. J. Food Prot.,70, 6: 1429-1433.

Kang, H.J.; Jo, C.; Kwon, J.H; Kim, J.H.; Chung, H.J. and Byun, M.W. (2007): Effect of a pectin-based edible coating containing green tea powder on the quality of irradiated pork patty. J. Food Control, 18, 5: 430-435.

Ko, S.Y. and Yang, C.J. (2008): Effect of green tea probiotics on the growth performance, meat quality and immune response in finishing pigs. Asian-Austalasian J. Animal Sciences, 21(9): 1339-1347

Kim, S.; Ruengwilysup, C. and Fung, D.Y. (2004): Antibacterial effect of water-soluble tea extracts on food borne pathogens in laboratory medium and in a food model. J. Food Prot. 67(11): 2608-2612.

Kumudavally, K.V.; Phanindrakumar, H.Si.; Tabassum, Aisha; Rad Kakrishna, K. and Rawa, A.S. (2008): Green tea - Apotential preservative For extending the shelf life of fresh mutton at ambient temperature $\left(25 \pm 2 \mathrm{C}^{\circ}\right)$. J. Food Chemistry 107, 1: 426-433.

Kuroda, Y. and Hara, Y. (1999): Antimutagenic and anticarcinogenic activity of tea polyphenols. Mutat. Res.; 436 (1): 60-67.

Maolinchun, D. (2006): Effects of tea polyphenols on fresh-keeping of partial frozen crucian (Carassius Auratus). J. of Chinese Institute of Food Science and Technology-4.

Nam, K.C.; Ahm, D.U.; DU, M. and Je, C. (2001): Lipid oxidation, colour, volatiles and sensory Characteristics of aerobically packaged and irradiated pork with different ultimate. J. of Food Sci., 66: 1225-1229.

Nirmal, N.P. and Benjakul, Soottawat (2010): Effect of green tea extract in combination with. ascorbic acid on the retardation of melanosis and quality changes of pacific white shrimp during iced storage. J. Food and Bioprocess Technology DoI: 10, 1007/s1194-0483-5. 
Noriyuki, I.; Toshiyoshi, A.; Yutaka, Г.; Misa, I.; Akifumi, Nobuyki, A.; Chi, C.D.; Rai, J.L. and Tatsuo, M. (2001): Suppressive effects of green tea polyphenols on Microbial growth and volatile Basic Nitrogen content in Round form yellowtail (Serioal quinqueradiata) meat during ice storage. Food Preservation Sci. J., 27, 5: 269-276.

Qualhas, I.; Petisca, C.; Viegas, O.; Meio, A.; Pinho, O. and Ferreira, I.M. (2010): Effect of green tea marinades on the formation of heterocylice aromatic amines and sensory quality of pan-fried beef. J. of Agricultural and Food Chemistry, 56,: 10625-10632.

Rababah, I.M; Ereifej, K.I.; Al-Mahasenh, M.A. and AL Robabah, M.A. (2006-a): Effect of plant extracts on physicochemical properties of chicken breast meat cooked using conventional electric oven or microwave. J. of Poultry Sci., 85: 148-154.

Rababah, .; Hettiarachchy, N.S.; Horax, R.; Davis, B. and Dicksons, J. (2006-b): Thiobarbituric acid reactive substances and volatile compounds in chicken breast meat infused with plant extracts and subjected to electron beam irradiation J. of Poultry Sci., 85: 1107-1113.

Sakanaka, S.; Aizawa, M.; Kim, M. and Yamamoto, Г. (1996): Inhibitory effect of green tea polyphenols on growth and cellular adherence of an oral bacterium, porphyromon as gingivalis. Biosci Biotechnol Biochem, 60: 745-749.

Sakanaka, Senýi; Juneje, Lekh, Raj and Taniguchi, Makoto (2000): Antimicrobial effects of tea polypoenols on thermophilic sporeforming bacteria. J. of Bioscience and Bioengineering, 90, 1: 81-85.

Sarah, H.; Hadiseh, K.; Gholamhossein, A. and Bahareh, S. (2010): Effect of green tea (Camellia sinenses)) extract and onion (Allium cepa) juice on lipid degradation and sensory acceptance of persian sturgeon (Acipenser persicus) fillets. International Food Res. J., 17: 751-761.

Sarker, M.S.K.; Kim, G.M. and Yang, C.J. (2010): Effect of green tea and biotie on performance, Meat quality and organ development in Ross broile. J. of Egypt. Poult. Sci., 30, 1, pp: 77-88.

Sikorski, Z.E.; Kolakowska, A. and Burt, J.R. (1990): Postharvest biochemical and microbial changes. In sikoreski, Z.E. (Ed). Seafood: Resources, nutritional composition and preservation: 55-72. Boca Raton, FL: CRC press, Inc. 
Traci, P.A. and Duncan, C.L. (1974): Cold shock and lethality in Clostridium perfringens. Appl. Microbial., 28: 815-821

Vasudeo, Z. and Sonika, B. (2009): Antimicrobial activity of tea (Camellia sinesis). The Internet J. of Nutrition and Wellness, 8,1 .

Vyncke, W. (1970): Direct determination of the thiobarbituric acid value in trichloroacetic acid extracts of fish as a measure of oxidative rancidity. Fette-Seifen Astrichmittel, 2: 1084-1087. 